\title{
PROBLEMATIKA PEMBELAJARAN SASTRA BAHASA INDONESIA DI SEKOLAH DASAR
}

\author{
Fuaduddin \\ Institut Agama Islam (IAI) MuhammadiyaBima \\ fuaduddiniaimbima@gmail.com
}

\begin{abstract}
Abstrak
Pengajaran sastra harus memiliki efek yang melekat pada diri siswa. Sehingga siswa dapat mengimplementasikan hasil pengajaran sastra sebagai dasar budi dan nilai-nilai luhur yang termuat dalam kegiatan besaastra. Makna sastra sebagai dulce et until (indah dan bemakna) harus melekat pada siswa yang beroleh pengajaran sastra. Demi mencapai pengajaran sastra yang ideal tersebut, maka pembelajaran sastra harus didukung oleh berbagai instrumen pendukung. Diantra instrumen pendukung dalam pengajaran sastraa adalah (1) tersedianya sarana dan praasarana; (2) siswa sebaai komponen subyek pelaksana pembelaajaran sastra; dan (3) guru sebagai pengatur dalam menjalankan proses pembelajaran sastra. Meskipun persolalan yang dihadapi oleh setiap siswa dalam proses pembelajaran apresiasi sastra menjadi objek yang menarik untuk diteliti. Metodologi penelitian dengan studi kasus adalah merupakan suatu pendekatan yang mendalam untuk memahami persoalan atau kendala yang dihadapi dalam proses pembelajaran atau pada kasus tertentu. Pentingnya memecahkan persoalan yang dihadapi merupakan tuntutan bagi pengajar maupun pemerhati pendidikan, khususnya bagi pembelajaran di sekolah. Berbagai problema yang dihadapi oleh siswa baik scara umum maupun kasus yang bersifat khusus pada siswa tertentu merupakan keharusan untuk dicarikan soslusinya. Pembelajaran apresiasi sastra memang menjadi persolan rumit ditengah berbagai polemik yang terjadi diantara pelaksana pengajaran apresiasi sastra di sekolah dan pemerintah sebagai regulator pelaksana kebijakan pendidikan.
\end{abstract}

Kata Kunci: Pembelajaran, Sastra, danBahasa

\section{PENDAHULUAN}

$\mathrm{P}$ engajaran sastra, patut diakui belum mampu menghasilkan pencapaian yang maksimal. Pandangan itu termanifestasi dari berbagai pengalaman praktek dan evaluasi terhadap pembelajaran sastra di sekolah khususnya sekolah dasar (SD). Berdasarkan berbagai kajian ilmiah dan forum ilmiah yang digelar dalam 
rangka mengevaluasi pengajaran sastra di sekolah, menyimpulkan adanya persolan dalam pengajaran sastra. Kholid A. Haras (2010) mengatakan bahwa pencapaian dalam capaian pengajaran sastra senantiasa sangat memprihatinkan. Situasi itu menyebabkan siswa mengalami 'rabun sastra' mengutip pandangan sastrawan Taufik Ismail. Permasalahan pengajaran satra tersebut mengharuskan kita untuk menemukan solusi yang tepat terhadapa problematika pengajaran sastra.

Ketidaktuntasan pembelajaran sastra dalam pengajaran di sekolah dasar memang tidak hanya diakibatkan oleh satu faktor. Namun terdapat faktor yang kompleks sehingga menambah kerumitan dalam menentukan solusi terhadap persoalan pengajaran apresiasi sastra. Secara umum faktor yang menyebabkan ketidak maksimalan dalam pengajaran apresiasi sastra terdiri dari tiga faktor umum yaitu, kualitas guru, siswa dan fasilitas. Faktor-faktor ini cukup dominan dalam mempengaruhi aktifitas pembelajaran sastra. Dari faktor umum itu, tentunya pengaruh persolan dari guru dan murid juga menjadi komponen yang mempengaruhi kemampuan mencapai ketuntusan belajar apresiasi sastra. Menurut pandangan Iskandar Waasid, bahwa pengajaran sastra maupun mengajaran secara umum ditentukan oleh faktor proses pembelajaran (teaaching learning proses) yang kemudian didukung oleh beberapa faktor pendukung yaitu, raw input, instrumental input (infrastruktur), environmental input (masukan lingkungan). Ketiga faktor itu hanya sebagai pendukung terhadap proses pembelajaran yang kemudian akan menghasilkan output pembelajaran. Khususnya pada komponen raw Input, yang berkenaan dengan unsur internal yang dimiliki oleh siswa seperti minat, motifasi, intelegensi dan sebagainya juga sangat mempengaruhi ketuntasan dalam pembelajaran apressiasi sastra. Terkait faktor tersebut persoalan yang dihadapi oleh siswa sekolah dasar dalam komponen itu berbeda-beda. Ada siswa yang tidak mengalami banyak hambata dalam komponen itu, namun ada juga yang bermasalah. Kesemuanya itu merupakan bagian dari persolan proses pembelajaran apresiasi sastra.

Persolalan yang dihadapi oleh setiap siswa dalam proses pembelajaran apresiasi sastra menjadi objek yang menarik untuk diteliti. 
Metodologi penelitian dengan studikasus adalah merupakan suatu pendekatan yang mendalam untuk memahami persoalan atau kendala yang dihadapi dalam proses pembelajaran atau pada kasus tertentu. Pentingnya memecahkan persoalan yang dihadapi merupakan tuntutan bagi pengajar maupun pemerhati pendidikan, khususnya bagi pembelajaran di sekolah. Berbagai problema yang dihadapi oleh siswa baik scara umum maupun kasus yang bersifat khusus pada siswa tertentu merupakan keharusan untuk dicarikan soslusinya. Pembelajaran apresiasi sastra memang menjadi persolan rumit ditengah berbagai polemik yang terjadi diantara pelaksana pengajaran apresiasi sastra di sekolah dan pemerintah sebagai regulator pelaksana kebijakan pendidikan. Dalam dealektika persoalan tersebut pasti akan banyak persoalan "kasus" yang dihadapi oleh para pembelajar. Persolanpersoalan tersebut harus ditangani dengan baik, supaya mendapatkan solusi yang terbaik pula. Untuk itu dalam artikel ini akan dipaparkan beberapa hal yang berkaitan dengan persolan pembelajran apresiasi sastra khususnya persoalan yang bersifat khusu "kasus" yang mungkin akan dialami oleh individu-individu tertentu dalampembelajaran apresiasi sastra.

\section{Studi Kasus Dalam Pembelajaran Bahasa Indonesia dan Sastra}

Studi kasus dalam pembelajaran apresiasi sastra adalah bentuk penelitian apresiasi sastra yang mendalam tentang suatu aspek apresiasi sastra, termasuk lingkungan apresiasi sastra dan manusia yang terlihat dalam proses apresiasi sastra. Oleh karena beberapa klasifikasi kasus sebagai objek studi dan kasus lainnya dianggap sebagai suatu metodologi. Maka penjelasan studi kasus merupakan studi yang mendetail yang dapat menggunakan banyak sumber data untuk menjelaskan sebuah variabel atau hal yang diteliti. Kasus bisa dipilih karena keunikannya atau kasus bisa digunakan untuk mengilustrasikan suatu isu.Studi kasus dalam pembelajaran apresiasi sastra dapat dilakukan terhadap seorang individu, sekelompok individu, lingkungan hidup manusia, serta lembaga sosial yang terkait dengan proses pembelajaran apresiasi sastra. Studi kasus dalam pembelajaran apresiasi 
sastra dapat difokuskan pada berbagai aspek kompetensi pembelajaran apresiasi sastra.

Pengajaran sastra memiliki berbgai dimensi untuk dicapai. Menurut Ismawati Esti (2013: 1) aspek pengajaran sastra meliputi teori sastra, sejarah sastra, satra bandingan dan apresiasi sastra. Pengajran satra merupakan pengajaran yang meliputi seluruh aspek tersebut. Pengajaran sastra di sekolah harus dinilai dalam tiga aspek kemampuan siswa yaitu, aspek kognitif, aspek afektif dan aspek psikomotorik. Menurut Ismawati Esti (2013:134) Aspek kognitif berkaitan dengan pengetahuan dan proses berpikir; aspek afektif pembelajaran sastra berkaitan dengan aktifitas otot, fisisk atau gerkan badan yang diimplemetasikan dalam betuk ketermapilan-keterampilan yang berkaitan dengan apresiasi sastra. Dari keseluruhan aspek pengjaaran sastra, aspek apresiasi sastra cukup sulit diimplementasikan dalam proses pengajaran khususnya dalam mengukur kemampuan apresiasi. Kesulitan ini terjadi karena dalam proses apresiasi lebih banyak melibatkan ranah afeksi. Pengajaran apresiasi satra di sekolah harus dilakukan untuk mencapai proses apresiasi yang sesungguhnya. Hal itu dapat dilakukan dengan melakukan beberapa tahapan. Menurut Ismawati Esti (2013: 1-2) pengjaran sastra di sekolah dilakukan dalam beberapa tingkatan yaitu:

1. Tingkat menggemari, yang ditandai dengan sikap ketertarikan menggeluti buku-buku sastra yang meliputi buku sastra yang berkaitan dengan teori sastra, sejarah sastra, kritik sastra, sastra bandingan, dan sebagainya.

2. Tingkat menikmati ditunjukkan dengan sikap menikmati cipta sastra yang dilandasi dengan tumbuhnya pengertia. Sikap menikmati ditunjukkan dengan menunjukkan sikap positif dan menghargai cipta sastra dengan penuh jiwa.

3. Tingkap mereaksi yang ditandai dengan sikap memberikan pandangan dan pendapat tentang cipta satra yang dinikmati melalui kegiatan menulis resensi, terlibat dalam diskusi-diskusi saatra, adanya keinginan untuk berpartisipasi dalam kegiatan sastra, dan keinginan untuk menciptakan kariya sastra. 
4. Tingkat memproduksi yaitu denngan menunjukan sikap menghasilakan cipta sastra baik secara profesional maupun amatiran.

Dari tingkatan kegiatan apresiasi sastra dalam pembelajaran sasatra tersebut, kegiatan apresiasi merupakan kegiatan untuk menuju apresiasi yang sesungguhnya. Tidak hanya melakukan proses penilaian dan penghargaan semata, namun juga harus dilaksanakan dalam bentuk kegiatan yang konkret dan menghasilkan sesuatu yang nyata. Idealnya proses apresiasi sastra harus termanifestasi daam kegiatan yang komprehensif. Menurut Ismawati Esti (2013: 117) idealnya proses apresiasi sastra harus dimaknai sebagai kegiatan menggauli, menggeluti, memahami, menikmati cipta sastra sehingga tumbuh pengetahuan, pengertian, kepekaan, pemahaman, penikmatan, dan penghargaan terhadap cipta sastra yang kita gauli, geluti, pahami, dan nikmati. Artinya apresiasi sastra merupakan sikap yang melibatkan ranah afektif yang berhubungan dengan sikap dan nilai. Sehingga pembelajaran sastra tidak hanya menjadi kegiatan yang berlangsung singkat, tapiharusberlangsungsecaraterus-menerusdanberkelanjutan sampai pada waktu setelah proses pengajaran berlangsung.

Pengajaran sastra harus memiliki efek yang melekat pada diri siswa. Sehingga siswa dapat mengimplementasikan hasil pengajaran sastra sebagai dasar budi dan nilai-nilai luhur yang termuat dalam kegiatan besaastra. Makna sastra sebagai dulce et until (indah dan bemakna) harus melekat pada siswa yang beroleh pengajaran sastra. Demi mencapai pengajaran sastra yang ideal tersebut, maka pembelajaran sastra harus didukung oleh berbagai instrumen pendukung. Diantra instrumen pendukung dalam pengajaran sastraa adalah (1) tersedianya sarana dan praasarana; (2) siswa sebaai komponen subyek pelaksana pembelaajaran sastra; dan (3) guru sebagai pengatur dalam menjalankan proses pembelajaransastra.

Sarana dan praasarana pendukung dalam pembelajaran sasatra adalah berupa properti dan fasilitas pendukung lainnya. Fasilitas pendukung bisa berupa pneyediaan buku yang berkaitan dengan pengajaran sastra, dan buku atau teks tentang sastra. Sementara murid juga harus ikut berperan dalam pengajaran sastra dengan menunjukkan 
sikap gairah, termotivasi dan berkeinginan kuat untuk mengikuti pelajaran sastra. Untuk menciptakan situasi tersebut dibutuhkan guru yang kompeten dalam mengajarkan sastra. Guru yang kompeten dalam pengajaran sastra menurut Ismawati Esti (2013: 117) adalah dilihat dengan tersedianya guru sastra yang dapat dijadikan model, teladan, contoh, bagi peserta didiknya dalam hal pembelajaran sastra.

Khusus yang berkaiatan dengan murid sebagai subyek dalam proses pebelajaran sastra, tentunya dari sekian murid yang terlibat dalam penggajaran sastra pasti ada persolan yang bersifat individualistik yang dapat kita temukan dalam proses apresiasi. Persolan yang dihadapai oleh invidu atau kelompok tersebut misalnya kesulitan siswa atau individu tertenntu dalam memahami atau mencapai ketuntasan pembelajaran apresiasi sastra. Kesulitan dan ketidak tuntasan dalam proses pembelajaran apresiasi sastra terbut dapat dipengaruhi oleh berbagai faktor misalnya lingkungan, keluraga atau bahkan faktor internal siswa itu sendiri.

\section{Permasalahan dalam Pembelajaran Bahasa Indonseia dan Sastra}

Pembelajaran sastra erat kaiatannya dengan aspek humaniora pendidikan. berdasarkan rumpun ilmu bahwa ilmu budaya dan seni termasuk di dalamnya adalah satra merupakan bagiandari ilmu humniora, karena berkaitan dengan aspek kognisi yang melibatkan kepekaan rasa dan nilai-nilai kehidupan. Bagaimakah kaitan antara aspek humaniora pendidikan dengan permasalahan pembelajaran sastra? kalau kita analisis bahwa pendidikan kita saat ini sangat kering dari unsur humniora. Hal ini terindikasi dari visi pendidikan kita yang cenderung mengedepankan sains dan teknologi sebagia jawaban terhadap komptensi globalisasi. Keringnya unsur humaniora ini menyebabkan porsi pembelajaran yang berhubungan dengan ilmu humniora juga menjadi menurun. Dalamhalini, Nenden Lilis mengungkapakan hasil penelitian dari A. Khaedar Alwasilah, yang menemukan fakta bahwa di sekolah-sekolah satra hanya diajarkan sebanyak 23,6\%,. Dari porsi pengajaran tersebut pembelajran lebih ditekankan pada aspek pengetahuan kognitif, bukan afektif. 
Kenyataan ini mencerminkan bahwa target terhadap pencapaian pembelajaran sastra tidak maksimal. Pembelajran sastra yang seharusnya memberikan pengalaman dan pengalaman sastra seperti yang dikatakan oleh Prof. Dr. Iskandarwassid, M.Pd. bahwa output pembelajaran sastra adalah untuk memberikan pemngetahuan tentang sastra yaitu, teori sastra, sejarah sastra, dan kritik sastra serta memiliki pengalaman sastra yaitu, ekspresif (produktif) sastra, dan sikap reseptif. artinya kalau hanya mendapatkan porsi $23,6 \%$ pencapaian pembelajaran sastra akan terus mengalami keprihatinan. Tanpa dapat menghasilkan tujuan pembelajaran yang maksimal.

Selarasdenganpandangantersebut, Nenden Lilis A menyatakan bahwa ada beberapa faktor yang menyebabkan guru megalami kesulitan dalam melaksanakan pembelajaran sastra seperti yang diinginkan. Faktor-faktor terssebut adalah,

1. Kebijakan pemerintah yang selalu berubah-ubah lewat pergantian kurikulum.;

2. Sistem ujian nasional yang berjenis soal obyektif, memaksa guru mengambil jalan pintas melakukan pebelajaran dengan membahas soal-soal demi kelulusan siswa;

3. Adanya pembatasan lewat standar kopetensi lulusan (SKL) yang membuat para guru lebih terfokus untuk mengajar SKL ini; dan

4. Sarana dan prasarana yang tidak mendukung dalam proses pembelajran sastra.

Dari berbagai persolan umum kyang dilaami dalam proses pembelajaran apresiasi sastra tersebut, juga ada persolan yang berlaku khusus dalam pembelajaran apresiasi sastra. Persolan khusus tersebut bisa hadir dari faktor pendukung proses pembelajran, terhadap siswa, dan juga guru. Khususnya bagi siswa, persolan tersebut akan mempengaruhi kemampuan apresiasi siswa, sehingga akan menjadi faktor penghambat dalam pencapaian kompetensi apresiasi sastra.

\section{Aspek-Aspek Memungkinkan Terjadinya Persoalan dalam Apresiasi dalam Pembelajaran Bahasa Indonesia dan Sastra}

Sasaran dalam pengajaran apresiasi sastra adalah untuk mencaapai kompetensi pengajaran sastra. pengajaran apresiasi satra di 
sekolah harus dilakukan untuk mencapai proses apresiasi yang sesungguhnya. Hal itu dapat dilakukan dengan melakukan beberapa tahapan. Menurut Ismawati Esti (2013: 1-2) pengjaran sastra di sekolah dilakukan dalam beberapa tingkatan yaitu:

1. Tingkat menggemari, yang ditandai dengan sikap ketertarikan menggeluti buku-buku sastra yang meliputi buku sastra yang berkaitan dengan teori sastra, sejarah sastra, kritik sastra, sastra bandingan, dan sebagainya.

2. Tingkat menikmati ditunjukkan dengan sikap menikmati cipta sastra yang dilandasi dengan tumbuhnya pengertia. Sikap menikmati ditunjukkan dengan menunjukkan sikap positif dan menghargai cipta sastra dengan penuh jiwa.

3. Tingkap mereaksi yang ditandai dengan sikap memberikan pandangan dan pendapat tentang cipta satra yang dinikmati melalui kegiatan menulis resensi, terlibat dalam diskusi-diskusi saatra, adanya keinginan untuk berpartisipasi dalam kegiatan sastra, dan keinginan untuk menciptakan kariya sastra.

4. Tingkat memproduksi yaitu denngan menunjukan sikap menghasilakan cipta sastra baik secara profesional maupun amatiran.

Dari tingkatan kegiatan apresiasi sastra dalam pembelajaran sasatra tersebut, kegiatan apresiasi merupakan kegiatan untuk menuju apresiasi yang sesungguhnya. Tidak hanya melakukan proses penilian dan penghargaan semata, namun juga harus dilaksanakan dalam bentuk kegiatan yang konkret dan menghasilkan sesuatu yang nyata. Dari tingkatan tersebut, memungkinkan adanya persolan yang akan dihadapi siswa. Persolan bisa muncul dalam bentuk kesulitan untuk merealisasikan tingkatan kemampuan yang diharapakan.Secara kemampuan individu, pengajaran apresiasi sastra dapat dilihat dalam tiga rranah kemaampuan. Pembelajaran apresiasi sastra (fiksi) di sekolah setidaknya ada tiga aspek yang perlu diperhatikan. Menurut Ismawati Esti (2013: 141-142) aspek evaluasi apresiasi sastra adalah:

1. Aspek kognitif: yang berkaitan dengan pengetahuan mahasiswa terhadap berbagai teori yang mengandung apresiasi sastra (fiksi). Termasuk dalam unsur ini misalnya unsur-unsur yang membangun 
fiksi, baik unsur instriksik seperti penokohan (tokoh), alur (plot), setting, titik pandang (poin of view), gaya (style), dan sebagainya, maupun unsur ekstrinsik seperti biografi pengaraang, filsafat hidup pengarang. Kondisi sosial, ekonomi, budaya, dan sebagainya. Artinya aspek koginitif berkaitan dengan pemahaman konsep dan teoreti siswa dalam proses pembelajaran apresiasi.

2. Aspek emotif: bekaitan dengan perasaan emosional terhadap fiksi yang dibacanya. Termasuk dalam aspek ini misalnya kesan yang diperoleh setelah membaca fiksi, kenikmatan, menghayati apa yang dilakukan tokoh-tokohnya, simpati, antipati terhadap perilaku tokoh tertentu, dan sebagainya. Aspek emosi lebih menekankan pada perasaan dan nilai yang diperoleh dalam pembelajaran apresiasi.

3. Aspek evaluatif: berkaitan dengan penilaian apresiator atas fiksi yang dibacanya. Termasuk dalam aspek ini misalnya: apakah fiksi yang dibaca tersebut sesuai atau tidak sesuai dengan nilai-nilai yang ada di masyarakat, apakah fiksi tersebut cukup baik, indah sebagai karya sastra dan sebagainya. Aspek penilaian merupakan sebuah interpertasi siswa dalam membeikan penilaian yang komprehensif terhadap sastra.

Dengan berbagai aspek penilaian tersebut menggambarkan bahwa pengajaran apresiasi sastra memerlukan proses pembelajaran yang kompleks dan lengkap. Sekaitan dengan itu pembelajaran sastra yang mendukung terhadap pembelajaran sastra yang sebenarnya harus didukung oleh berbagai instrumen pembelajaran yang kompleks. Ketuntasan dalam pencapaian ketiga ranah tersebut tentunya akan banyak mengalami tantangan. Tantangan tersebut misalnya kesulitan siswa dalam mencapai ketuntasan kognitif, emotif dan evaluatif.Disamping persolan umum yang dipaparkan di atas, beberapa persolan khusus yang dialami oleh individu-individu tertentu juga mewarnai kompleksnya persoalan pengajran apresiasi sastra di sekolah. Beberapa persolan khusus yang dimaksud adalah berkaitan dengan hambatan dan kesulitan siswa tertentu dalam ketuntasan kompetensi pembelajran apresiasi sastra dalam berbagai tingkatan pembelajran sastra 
maupun dalam raanah pencapaian kompetensi pembelajaran apresiasi sastra.

Persoalan tersebut bias diakibatkan oleh beberapa faktor misalanya (1) faktor lingkungan anak berada, (2) faktor keluarga dimana anak dibesarkan, dan (3) faktor internal siswa yang bisa berupa kondisi psiskis dan non psikis. Persolan tersebut bisa mememiki kecenderungan dalam mempengaruhi kemampuan anak yang mengalami persolan. Tentunya terkait kecenderungan yang mana akan dialami oleh anak akan ditentukan oleh berbagai faktor yang mempengaruhi tersebut. Bisa saja kecenderungan tersebut hadir dari persolan lingkungan sosial anak berada, lingkungan keluar, faktor initernal yang berupa psikis maupun non psikis. Persoalan ini bisa berpengaruh pada persoalan tingkatan apresiasi sastra misalnya:

1. Tingkat menggemari, anak yang tidak memiliki motivasi dan minat dalam pembelajaran apresiasi sastra akan sulit menggemari pembelajran sastra. Hal ini bisa saja dipengaruhi oleh berbagai faktor misalnya ada pandangan tentang mempelajari sastra tidak memiliki faedaah dan manfaat, atau karena lingkungan sosial dan keluraga yang tidak memberikan wawasa tentang kesastraan.

2. Tingkat menikmati misalnya ditunjukkan dengan ketidak nyamanan siswa dalam mengikuti pembelajran sastra, siswa tidak menempatkan rasa dan jiwanya dalam merespon pembelajran sastra.

3. Tingkap mereaksi yang ditandai dengan sikap yang dingin dan tidak memberikan respon, pandangan, dan pendapat tentang cipta satra yang dinikmati melalui kegiatan menulis resensi, terlibat dalam diskusi-diskusi saatra, adanya keinginan untuk berpartisipasi dalam kegiatan sastra, dan keinginan untuk menciptakan kariya sastra.

4. Tingkat memproduksi yaitu dengan tidak menunjukan sikap menghasilakan cipta sastra baik secara profesional maupun amatiran.

Di samping tentang persolan tingkatan pembelajran apresiasi sastra tersebu, siswa juga akan mengalami persolan kemampuan individu, pengajaran apresiasi sastra dapat dilihat dalam tiga ranah kemaampuan. Pembelajaran apresiasi sastra (fiksi) yaitu. 
1. Ketiadaan aspek kognitif: yang berkaitan ketiadaan pengetahuan mahasiswa terhadap berbagai teori yang mengandung apresiasi sastra (fiksi). Termasuk dalam unsur ini misalnya unsur-unsur yang membangun fiksi, baik unsur instriksik seperti penokohan (tokoh), alur (plot), setting, titik pandang (poin of view), gaya (style), dan sebagainya, maupun unsur ekstrinsik seperti biografi pengaraang, filsafat hidup pengarang. Kondisi sosial, ekonomi, budaya, dan sebagainya. Artinya aspek koginitif berkaitan dengan pemahaman konsep dan teoreti siswa dalam proses pembelajaran apresiasi. Ketiadaan kognitif siswa bisa saja disebabkan oleh faktor tidak adanya minat dan motifasi siswa dalam menggemari pembalajran.

2. Ketiadaan aspek emotif: dengan menunjukan sikap yang tidak merespon nilai-nilai yang terkandung dalam proses pembelajaran sastra misalnya perasaan emosional terhadap fiksi yang dibacanya. Termasuk dalam aspek ini misalnya kesan yang diperoleh setelah membaca fiksi, kenikmatan, menghayati apa yang dilakukan tokohtokohnya, simpati, antipati terhadap perilaku tokoh tertentu, dan sebagainya. Aspek emosi lebih menekankan pada perasaan dan nilai yang diperoleh dalam pembelajaran apresiasi.

3. Ketiadaan aspek evaluatif: berkaitan dengan penilaian apresiator atas fiksi yang dibacanya. Termasuk dalam aspek ini misalnya: apakah fiksi yang dibaca tersebut sesuai atau tidak sesuai dengan nilai-nilai yang ada di masyarakat, apakah fiksi tersebut cukup baik, indah sebagai karya sastra dan sebagainya. Aspek penilaian merupakan sebuah interpertasi siswa dalam membeikan penilaian yang komprehensif terhadap sastra.

\section{SIMPULAN}

Berbagai aspek tujuan pengajaran sastra, menggambarkan bahwa pengajaran apresiasi sastra memerlukan proses pembelajaran yang kompleks dan lengkap. Kaitan dengan hal itu pembelajaran sastra yang mendukung terhadap pembelajaran sastra yang sebenarnya harus didukung oleh berbagai instrumen pembelajaran yang kompleks. 
Ketuntasan dalam pencapaian ketiga ranah tersebut tentunya akan banyak mengalami tantangan. Tantangan tersebut misalnya kesulitan siswa dalam mencapai ketuntasan kognitif, emotif dan evaluatif.Disamping persolan umum yang dipaparkan ada beberapa persolan khusus yang dialami oleh individu-individu tertentu juga mewarnai kompleksnya persoalan pengajran apresiasi sastra di sekolah. Beberapa persolan khusus yang dimaksud adalah berkaitan dengan hambatan dan kesulitan siswa tertentu dalam ketuntasan kompetensi pembelajaran apresiasi sastra dalam berbagai tingkatan pembelajran sastra maupun dalam ranah pencapaian kompetensi pembelajaran apresiasi sastra. Persoalan tersebut bisa diakibatkan oleh beberapa faktor misalnya (1) faktor lingkungan anak berada, (2) faktor keluarga dimana anak dibesarkan, dan (3) faktor internal siswa yang bisa berupa kondisi psiskis dan non psikis. Persolan tersebut bisa mememiki kecenderungan dalam mempengaruhi kemampuan anak yang mengalami persoalan. Tentunya terkait kecenderungan yang mana akan dialami oleh anak akan ditentukan oleh berbagai faktor yang mempengaruhi tersebut. Bisa saja kecenderungan tersebut hadir dari persolan lingkungan sosial anak berada, lingkungan keluar, faktor initernal yang berupa psikis maupun non psikis.

\section{DAFTAR PUSATAKA}

Abdul Chaer. 2003. Psikolinguistik (Kajian Teoretik). Jkarta: PT. Reneka Cipta.

Bambang Yudi Cahyono. 1995. Kristal-kristal Ilmu Bahasa. Surabaya: Airlangga University Press.

Dalaeh H. Schunk. 2012. Learning Theories (An Educational Perspective) terjemahan. Yogyakarta: Pustaka Pelajar.

Ismawati Esti. 2013. Pengajaran sastra. Yogyakarta: Ombak

Kholid A. Harras. 2009. Sejumlah Masalah Pengajaran Sastra (artikel). Bandung: FPBS Universitas Pendidikan Indonesia.

Rusyana Rus. 1984. Bahasa dan Sastra (dalam Gamitan Pendidikan). Bandung: CV. Diponegoro. 